\title{
Use of scoria waste as subbase stabilization material for highway flexible pavement
}

\author{
Mehmet Saltan $^{\mathrm{a}}{ }^{*}$ (iD), F. Selcan Ozen ${ }^{\mathrm{b}}$ (D) \\ aCivil Engineering Department, Engineering Faculty, Suleyman Demirel University, Turkey $\mathrm{K}$ \\ bMinistry of Transport, Maritime Affairs and Communications, Ankara, Turkey
}

\section{Highlights}

- Scoria is a well-known lightweight aggregate.

- Scoria waste has a potential for usage as subbase stabilization materials.

- Durability of volcanic slag is appropriate for subbase.

\begin{abstract}
Usability of scoria waste as subbase stabilization material was investigated. Initially, the physical properties of scoria waste were examined. The usage of scoria waste in subbase layer of the pavement was investigated. In the study, experimental researches such as stability to freeze, solidity, strength, Atterberg limits and California Bearing Ratio tests were carried out on samples prepared by using scoria waste. Scoria and natural quarry materials were blended in different amounts to prove the percentage of plastic limit. Then, the limit tests were carried out on the prepared mixtures. The strength of the samples obtained by using reusable material was determined with the California Bearing Ratio (CBR) test. According to the obtained results, it was observed that the usage of scoria wastes as stabilization material in the subbase layer of flexible pavements is appropriate. Moreover, mechanical stabilization with scoria wastes has positive impact in increasing of the mechanical properties of the new mixed composite material.
\end{abstract}

Information
Received:
25.11.2020
Received in revised:

19.03.2021

Accepted:

19.04.2021

Keywords: Flexible pavement, scoria, subbase, stabilization

\section{Introduction}

The pavement is the surface which subjected to directly the weather conditions and the moving vehicles on it. At the same time, the aim of the pavement is to ensure the friction of the moving vehicles against sliding and to transmit the stresses which created by the vehicles to the underlying layers and soil. Flexible pavements studied here were created by using bituminous materials and aggregates.

Flexible pavements consist of layers such as subbase, base and coating layers which have different properties. The coating layer which constructed as hot mixture asphalt (HMA) is designed in two ways as wearing coarse and binder course. Base layer can be made by using aggregates with certain gradation properties or HMA. The subbase layer is constructed depending on climatic factors and CBR value of subgrade
Since the stresses transmitted from the upper layers to the subbase layer are less, the quality of the materials used in the subbase layer are lower than the materials which used in other layers. [1]. Therefore, it is economically preferred to usage of local and waste materials in the subbase layer.

Generally, crushed stone used in the subbase layer is more expensive than natural materials. Especially waste and local materials can be used as a stabilization material in the subbase layer [2].

Scoria is a well-known lightweight aggregate. Terminologically, scoria is a natural vesicular glassy lava rock transformed with open pit mining for an industrial material. For nearly three centuries, scoria was successfully used in more than 70 different applications all around the world $[3,4]$.

Scoria is non-plastic light weight aggregate. With its nonplastic feature, scoria is mixed with lend material which is 
out of specification limits in terms of plasticity in definite ratio; the derived new mixture can be used as a highway material.

In the current study, scoria waste which has dimensions of $3 \mathrm{~mm}$ and less than $3 \mathrm{~mm}$ was used as a mechanical stabilization material in the subbase layer of flexible pavement. First, tests were carried out to determine whether usage of scoria waste material is suitable in the subbase layer or not. After, scoria was used as a stabilization material in the subbase layer.

\section{Flexible Pavements}

A flexible pavement is a multi-layer system formed by the coating layer which is consist of both aggregates and bituminous material and the base and subbase layers which are generally composed of aggregates, on natural soil [5]. Each pavement layers transfers the loads to the below layer by spreading. Lower layers carry less load. In other words, the lower pavement layers receive lower vertical pressure.

A flexible pavement consists of various components. The mechanical behaviour of the bituminous and granular layers comprising the flexible pavement varies $[6,7]$.

The flexible pavement is designed considering engineering and economic factors. While the coating and base layers are important in terms of high performance, the subbase layer is important for economic design.

The main aim of the subbase layer of a pavement is to reduce the design cost. The purpose of the construction of subbase layer is to get required total pavement thickness with the possible economic materials. In this context, the materials used in the upper layers are of higher quality than the materials used in the subbase layer in order to ensure the strength of the pavement and the subbase layer is thicker than other layers because of having lower quality materials. Although the total pavement thickness may increase, it is generally preferred to construction of the base layer thinner and usage of low-quality materials in subbase layer [8].

Subbase layer provides load transfer from base layer to subgrade by decreasing gradually the inner stress in the structure. Another important role of the sub-layers is to prevent the adverse effects of water in the structure by means of their granular texture. It acts as a drainage system to convey water from surface to the ground and reduce the capillary effect from the ground.

Examined physical properties of subbase layer in this study are defined in Table 1 [9]. A common method to determine the durability of granular materials is Sodium Sulphate Soundness test. Soundness test is conducted to analyse the resistance of granular materials to weathering conditions by applying accelerated weathering test cycles. Aggregates which exposed to the freeze-thaw cycles likely break down prematurely [10]. Another test to evaluate the aggregates is abrasion test. Abrasion test is applied to observe the hardness property of aggregates and to determine whether they are appropriate for different pavement construction conditions. Los Angeles abrasion test is used for this purpose specifically. The principle of Los Angeles abrasion test is to find the percentage of wear due to relative rubbing action between the steel balls which are used as abrasive power and aggregates [10]. The water content of the granular materials should be determined. For this purpose, following definitions are used. The liquid limit is defined as the moisture content which the soil changes from a plastic state to a liquid state. The plastic limit is defined as the moisture content which the soil changes from a semisolid state to a plastic state. All soils have not got a plastic limit. The numerical difference between the liquid limit and the plastic limit (LL-PL) is the plasticity index [11]. Finally, the strength of the granular materials should be tested. The CBR test is used to obtain an indication of strength of the materials [12].

Table 1. Physical characteristics which are given Turkish specification

$$
D_{200} / D_{40} 2 / 3
$$

$D_{200}$ : No.200 percentage of passing subbase material

$D_{40}:$ No.40 percentage of passing subbase material

Durability $\left(\mathrm{Na}_{2} \mathrm{SO}_{4}\right) \quad$ Lost $\leq \% 25$

Abrasion (Los Angeles) $\quad$ Abrasion $\leq \% 50$

Liquid Limit $\quad \mathrm{LL} \leq 25$

Plastic Index $\quad \mathrm{PI} \leq 6$

California Bearing Ratio $\quad$ CBR $\geq 30$

\section{Scoria}

Volcanic slag is a light-weight material and basaltic volcanic material; therefore, it is also named as basalt lava. It is also named cinders or volcanic cinder $[4,13,14]$. As a general review of forming the volcanic products, this material is a vesicular (bubbly) glassy lava rock of basaltic to andesitic composition ejected from a vent during explosive eruption [15].

Volcanic slag is also formed around of the cones during eruption or later it is transported around of the cones by erosion action. The cones usually have a height of several hundred meters, a symmetrical shape and variable slope angles depending on the age of the cone and its level of erosion [14].

Scoria forms when blobs of gas-charged lava are thrown into the air during an eruption and cool in flight, and then fallen as dark volcanic rock containing cavities crated by trapped gas bubbles [16]. Volcanic slag materials are typically reddish to black in colour, because of they contain iron mostly. The surface of some volcanic slag may have a dark green iridescent colour; oxidation may lead to a deep reddish-brown colour [17]. 
Volcanic slag is usually heavier, darker and more crystalline than pumice. Scoria is abundant in various parts of the world including Turkey, Papua New Guinea (PNG) [18] and Saudi Arabia [13].
Table 2. Chemical composition of scoria aggregate

\begin{tabular}{cccccc}
\hline Major Element & $\mathrm{SiO}_{2}$ & $\mathrm{Al}_{2} \mathrm{O}_{3}$ & $\mathrm{Fe}_{2} \mathrm{O}_{3}$ & $\mathrm{CaO}$ & $\mathrm{MgO}$ \\
Scoria & 48,43 & 17,2 & 8,9 & 9,18 & 4,96 \\
\hline
\end{tabular}

Table 3. Physical properties of scoria aggregate

\begin{tabular}{|c|c|c|c|c|c|c|c|c|}
\hline Sieve $(\mathrm{mm})$ & $>32$ & $16-32$ & 8-16 & $4-8$ & $2-4$ & $1-2$ & $0,5-1$ & $0,25-0,5$ \\
\hline Loose U.W. & 210 & 344 & 493 & 642 & 790 & 938 & 1086 & 1235 \\
\hline Compressed U.W. & 221 & 402 & 603 & 805 & 1003 & 1210 & 1461 & 1608 \\
\hline Water Absorption & 34,54 & 27,18 & 23,11 & 19,22 & 15,2 & 12,39 & 11,24 & 9,12 \\
\hline Void Ratio & 8,2 & 13,44 & 19,26 & 25,08 & 30,09 & 36,64 & 42,42 & 48,24 \\
\hline Porosity & 91,8 & 86,56 & 80,74 & 74,92 & 69,91 & 63,36 & 57,58 & 51,76 \\
\hline Degree of Saturation & 37,62 & 31,4 & 28,62 & 25,65 & 21,74 & 19,55 & - & - \\
\hline
\end{tabular}

U.W.: Unit Weight

Volcanic slag can be used in several industrial area including the producing of light-weight concrete, Portland-pozzolan cement additive, heat insulation, lowcost fillers, filter materials, absorbents, and some architectural purposes [19].

Volcanic slag aggregates were obtained from the scoria quarries in Manisa, Turkey. These materials were also crushed first. Then they were separated as fine scoria aggregates which have $0-4 \mathrm{~mm}$ size fractions and coarse scoria aggregates which have 4-8 $\mathrm{mm}$ size fractions.

\section{Experimental Study}

The chemical properties of volcanic slag are given in Table 2. The chemical characterization includes chemical analysis in order to determine the concentration of major, minor and some trace elements of volcanic slag.

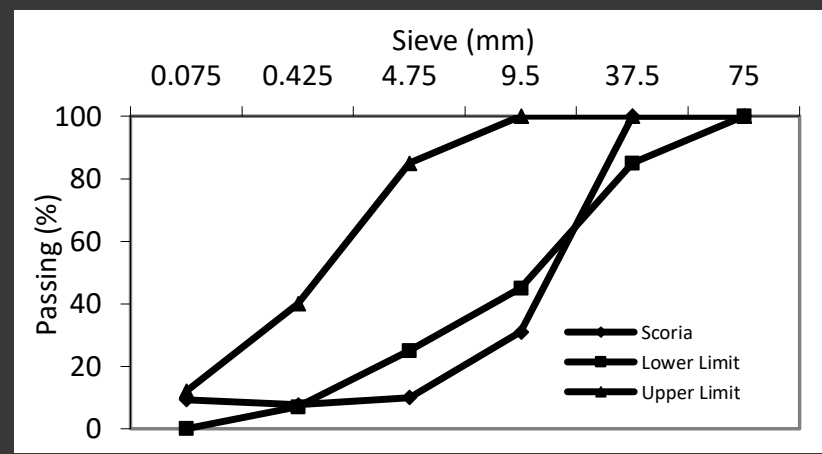

Figure 1. Granulometric curve of scoria aggregate

Scoria is rich highly in volcanic glass vesicles which give it high porosity besides low-density rock which is characterized by its dark colouring [20]. Porosity is the ratio of the volume of void to the total volume of material [21]. Physical properties of volcanic slag aggregates are given in Table 3. In Turkish Highway Flexible Pavement limitations [22], subbase layer materials must be within the upper and lower specification limits as demonstrated in Figure 1. Figure 1 shows the granulometric curves of volcanic slag aggregate. It is observed that granulometric line of volcanic slag is almost inside the specification limits.
CBR is a measure of shearing resistance of the soil under controlled density and moisture conditions. Therefore, the test cannot be considered as a classification test because the results are not constant for a given soil depending on factors such as size and shape of the particles as well as density and moisture content. The Los Angeles abrasion test is the most widely used test to evaluate the resistance of coarse aggregates to degradation by abrasion and impact. While performing the Los Angeles abrasion test, first the aggregate sample is washed, dried in the oven, and then separated into sieve sizes. The sieved material is recombined to a specified grading which corresponds nearly to the size range to be used. Following the completion of 500 revolutions, the sample is removed from the testing machine and sieved dry over a No.12 sieve. The percentage of the sample passed from No.12 sieve, named the percent of wear, is the Los Angeles abrasion of the sample [23]. The soundness of aggregates is considered a measure of the material's resistance to disintegration which is caused by weather actions such as alternate freezing and thawing, wetting and drying, heating and cooling, action of aggressive waters [24].

Table 4. Physical characteristics of scoria aggregate

\begin{tabular}{ccc}
\hline \hline & $\begin{array}{c}\text { Scoria Aggregate } \\
\text { Test Results }\end{array}$ & $\begin{array}{c}\text { Specification } \\
\text { Values }\end{array}$ \\
\hline Durability $\left(\mathrm{Na}_{2} \mathrm{SO}_{4}\right.$ ) & 12,90 & Loss $\leq \% 25$ \\
Abrasion (Los Angeles) & 53,93 & Abrasion $\leq \% 50$ \\
Liquid Limit & Non-plastic & $\mathrm{LL} \leq 25$ \\
Plastic Index & Non-plastic & $\mathrm{PI} \leq 6$ \\
California Bearing Ratio & 19,25 & $\mathrm{CBR} \geq 30$ \\
\hline \hline
\end{tabular}

Physical properties of volcanic slag material and specific values are shown in Table 4. Due to its characteristic, volcanic slag is categorised non-plastic material. Therefore, non-plastic volcanic slag material is not properly appropriate for subbase layer. The CBR test is a measure of the shear strength of the material when the samples are subjected to long soaking periods and allowed to swell. At the same time, the CBR method covers the determination of bearing ratio of pavement subgrade, subbase, and base course materials from laboratory-compacted samples. Although durability of 
volcanic slag is appropriate for subbase, the abrasion value is higher and the CBR value is lower than specification.

To obtain the optimum mixture design, the Los Angeles abrasion, durability, liquid limit, plastic limit and CBR tests were conducted in the experimental stage of the study. The detailed information is given in the following section.

\section{Stabilization Analysis}

A local appropriate sub-base material was selected to carry out the stabilization analysis (Figure 2). For this purpose, local material and volcanic slag aggregate were mixed in different proportions to obtain sub-base material. This mixture provides the specification limits.

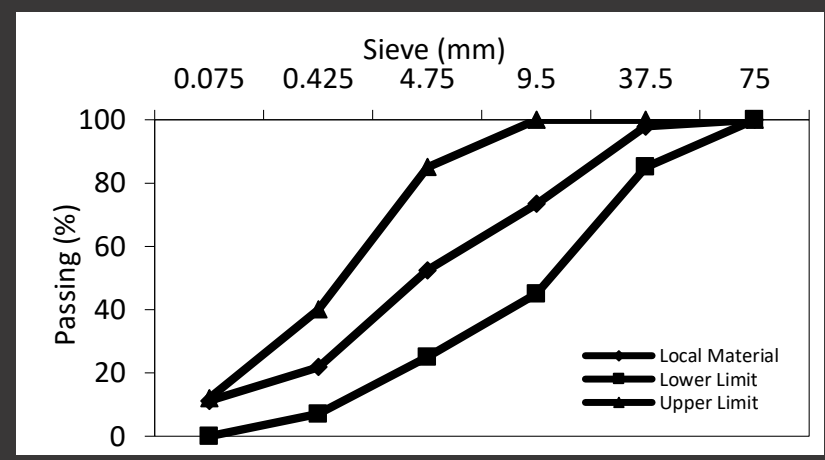

Figure 2. Granulometric curve of local lend material (the excavation area of this local material is located $60 \mathrm{~km}$ away from Isparta)

In view of physical properties, the local aggregate is appropriate for subbase layer because its durability value is 1.4 , abrasion value is 25.3 , and CBR value is 79 . But the granular material cannot be used in subbase layer directly because of the liquid limit (39) and plastic index values (17). These values should be 25 and 6, respectively. (Table 5). In order to use this material in subbase layer, these two specific values should be appropriate with the limits. To this end, the volcanic slag and the local material was blended to decrease the plasticity properties of the local material.

Table 5. Physical characteristics of local aggregate

\begin{tabular}{|c|c|}
\hline \multicolumn{2}{|c|}{ Local Material Experiment Results } \\
\hline Durability $\left(\mathrm{Na}_{2} \mathrm{SO}_{4}\right)$ & 1,4 \\
\hline Abrasion (Los Angeles) & 25,3 \\
\hline Liquid Limit & 39 \\
\hline Plastic Index & 17 \\
\hline California Bearing Ratio & 79 \\
\hline
\end{tabular}

Volcanic slag was mixed to local quarry material which is main subbase material in different ratios and it is examined that how liquid limit, plastic limit, and CBR values were affected after mixing process. At the beginning, $10 \%$ slag was added to the mixture and the mixing ratio was increased with $5 \%$ incrementally. Mixture prepared by using $25 \%$ scoria and $75 \%$ local aggregates indicated the best performance. According to the results of tests made on this mixture, $24 \%$ liquid limit, $2 \%$ plastic limit and 149.6 CBR values were obtained (Table 6). Accordingly, it was determined that, the mixture with this percentage meets fully the properties of the subbase layer material. The gradation limit for the mixture is as shown in Figure 3.

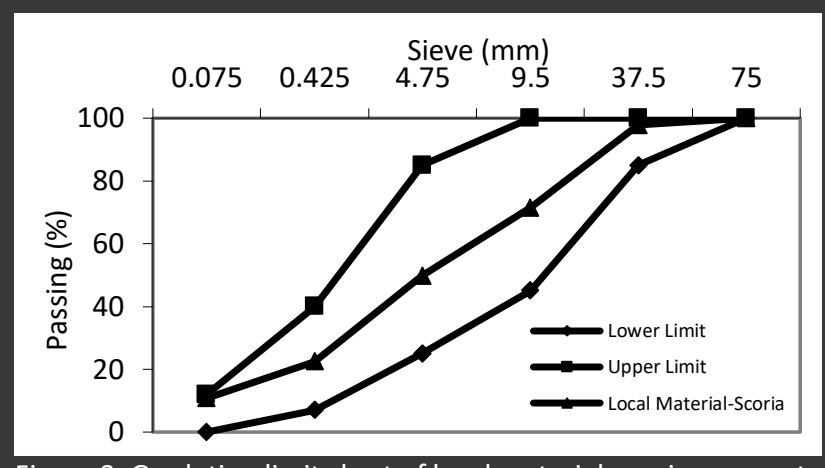

Figure 3. Gradation limit chart of local material-scoria aggregate mixture $(\% 75+\% 25)$

Table 6. Scoria and local material mixture ratios

\begin{tabular}{ccccc}
\hline \hline & \% Mixture & $\begin{array}{c}\text { Liquid } \\
\text { Limit }\end{array}$ & $\begin{array}{c}\text { Plastic } \\
\text { Index }\end{array}$ & CBR \\
\hline $\begin{array}{c}\text { Specification } \\
\text { Local }\end{array}$ & - & $\leq 25$ & $\leq 6$ & 30 \\
$10 \%$ & $90+10$ & 39 & 17 & 79 \\
$15 \%$ & $85+15$ & 29 & 13 & - \\
$20 \%$ & $80+20$ & 26 & 8 & 89,6 \\
$25 \%$ & $75+25$ & 24 & 2 & 110 \\
\hline \hline
\end{tabular}

As a result of this study, it was found that scoria is suitable as a stabilization material in the subbase layer of flexible pavement. The assessment of the experimental study is shown in the Figure 4. It is shown that the most suitable condition for stabilization process is $25 \%$ and higher than this ratio. CBR, plasticity index and liquid limit values are also shown in the Figure 4. So, three different specification parameters can be controlled at the same time. Lower CBR, upper liquid limit and plasticity index specification limit values are highlighted in the Figure 4.

\section{Conclusion}

Flexible pavement consists of a layered system which has different properties. Since stress is high in the coating layer, quality materials are used. On the contrary, low quality materials are used in the subbase layer which stress is low. Depending on this design principle, generally waste and local materials are used in the subbase layer. The use of waste and local materials in the flexible pavement reduces the design cost. Local quarry material is generally used in the subbase layer of flexible pavement in Turkey. Local materials from some granular subbase material quarry are not used because they do not meet the specification limit values. These limitation values must be determined using basically mechanical stabilization methods. In the study, such a mechanical stabilization method was studied and efficacious results were reached. 


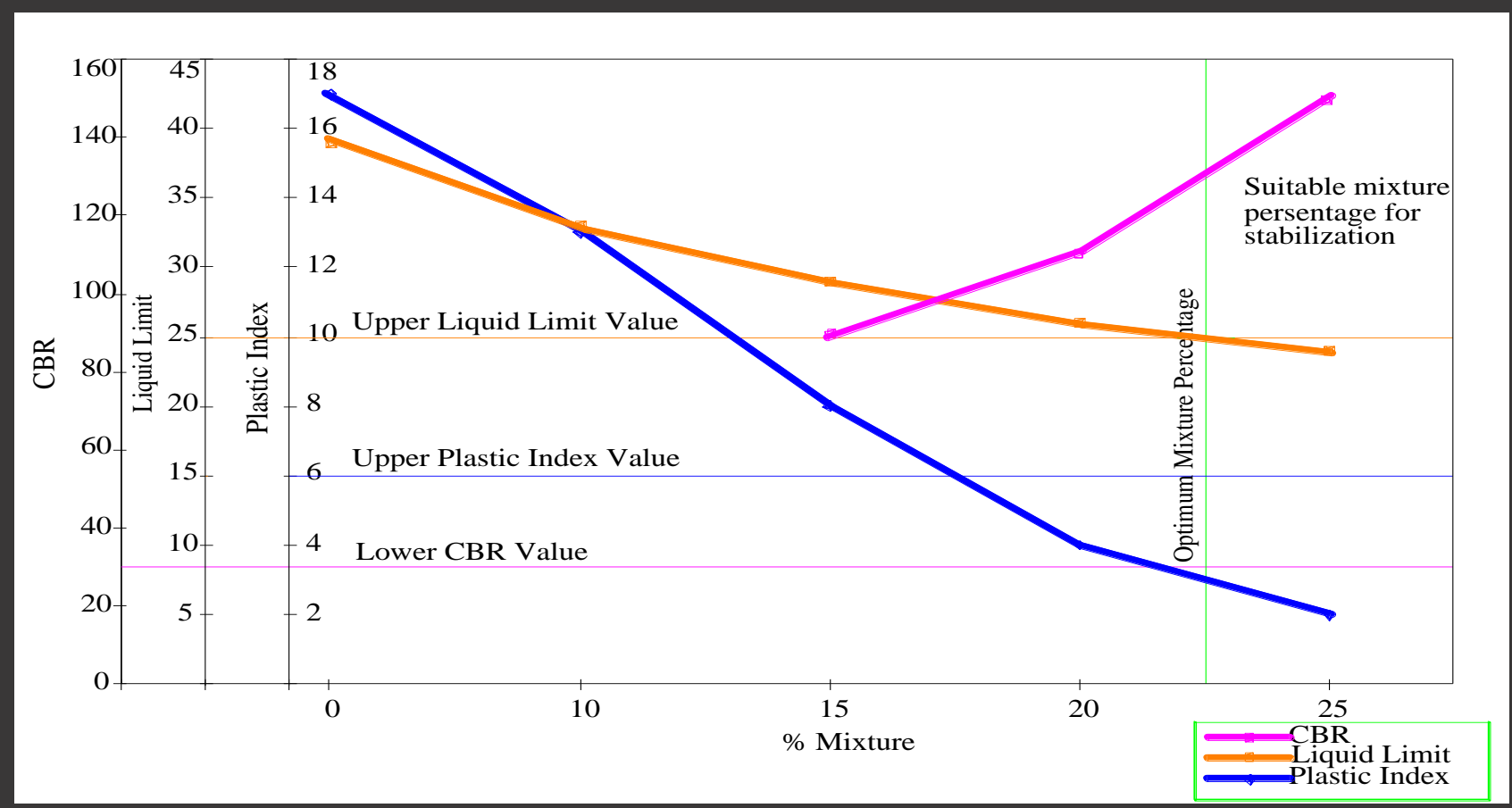

Figure 4. Evaluation of stabilized ratios

A local subbase material quarry is investigated in the current study. Obtained quarry materials are suitable for the subbase layer of flexible pavement except for consistency limits. For reducing the consistency limit values of local quarry material, scoria waste was blended with the quarry material. After the mixing, liquid limit and plasticity index values of the mixture were reduced to specification limit conditions. Moreover, a rising of $80 \%$ at CBR value was obtained after stabilization. Stabilization with scoria waste can provide economic and environmental benefits. Scoria waste is found locally and has no commercial value. As a result, mechanical stabilization of subbase layer material with scoria waste was found to be suitable for flexible pavements. This local granular material can be used as subbase material by General Directorate of Turkish Highways after this study.

\section{Declaration of Interest Statement}

The authors declare that they have no known competing financial interests or personal relationships that could have appeared to influence the work reported in this paper.

\section{Author Contribution Statement}

M. Saltan: Conceptualization, Data Curation, Formal Analysis, Investigation, Methodology, Project Administration, Resources, Supervision, Validation, Visualization, Writing - Original Draft - F. S. Ozen: Conceptualization, Data Curation, Formal Analysis, Investigation, Methodology, Resources, Writing - Original Draft, Writing - Review \& Editing

\section{References}

[1] Rico Rodriguez, A., del Castillo, H., \& Sowers, G. F. (1988). Soil mechanics in highway engineering. Series on rock and soil mechanics, 16 .

[2] Ahmed, I. (1991). Use of waste materials in highway construction. Joint Transportation Research Program, 299.

[3] Keller, J., Ryan, W. B. F., Ninkovich, D., \& Altherr, R. (1978). Explosive volcanic activity in the Mediterranean over the past 200,000 yr as recorded in deep-sea sediments. Geological Society of America Bulletin, 89(4), 591-604. https://doi.org/10.1130/0016-

7606(1978)89\%3C591:EVAITM\%3E2.0.CO;2

[4] Ritmann, L. (1976). Volcanoes. London, UK.

[5] Mulungye, R. M., Owende, P. M. O., \& Mellon, K. (2007). Finite element modelling of flexible pavements on soft soil subgrades. Materials \& Design, 28(3), 739-756. https://doi.org/10.1016/j.matdes.2005.12.006

[6] Huang, Y. H. (1993). Pavement analysis and design. http://worldcat.org/isbn/0136552757

[7] Findley, W. (1989) Creep and Relaxation of Non-linear Viscoelastic Materials. Prentice Hall.

[8] Saltan, M., \& Fındık, F. S. (2008). Stabilization of subbase layer materials with waste pumice in flexible pavement. Building and Environment, 43(4), 415-421. https://doi.org/10.1016/j.buildenv.2007.01.007

[9] TS 9581, (1991) Making Specification of Base and Subbase Layers of Flexible Pavement, Turkey.

[10] TS 699, (2000) Methods of Testing for Natural Building Stones, Turkey.

[11] TS 1900-1, (2006). Methods of Testing Soils for Civil Engineering Purposes in the Laboratory, Turkey.

[12] Demirel, Z., Kadıoğlu, M., Aray, S., Orhan, F. \& Alp, A. (1999) Earth and Stabilization Laboratory Handbook, K.G.M., Ankara. p. 180.

[13] Gass, I.G., Smith, P.J. \& Wilson, R.C.L. (1973) Understanding the Earth. Open University Set Book. p. 383. 
[14] Moufti, M. R., Sabtan, A. A., El-Mahdy, O. R., \& Shehata, W. M. (2000). Assessment of the industrial utilization of scoria materials in central Harrat Rahat, Saudi Arabia. Engineering Geology, 57(3-4), 155-162. https://doi.org/10.1016/S0013-7952(00)00024-7

[15] Gündüz, L. (2008). Use of quartet blends containing fly ash, scoria, perlitic pumice and cement to produce cellular hollow lightweight masonry blocks for non-load bearing walls. Construction and Building Materials, 22(5), 747-754. https://doi.org/10.1016/j.conbuildmat.2007.01.008

[16] Ercan, E., Türkecan, A., Dnçel, A., \& Günay, E. (1983). Geology of Kula-Selendi (Manisa) area. Jeoloji Mühendisliği, 17, 3-28.

[17] Demirdag, S., \& Gunduz, L. (2008). Strength properties of volcanic slag aggregate lightweight concrete for high performance masonry units. Construction and Building Materials, 22(3), 135-142. https://doi.org/10.1016/j.conbuildmat.2006.10.002

[18] Hossain, K. M. A. (2000). Reinforcement corrosion in volcanic ash and scoria based concrete. In Proc. Corrosion Asia Conference, Singapore, Paper (No. 16, pp. 145-151).

[19] Hossain, K. M. A. (2006). Blended cement and lightweight concrete using scoria: mix design, strength, durability and heat insulation characteristics. International Journal of Physical Sciences, 1(1), 005-016.

[20] Ercan, T., Dinçel, A., Metin, S., Türkecan, A, \& Günay, E. (1978). Uşak yöresindeki Neojen havzalarının jeolojisi. Bulletin of the Geological Society of Turkey, 21, 91-106.

[21] Budhu, M. (2000) Soil Mechanics and Foundations. New York: Wiley.

[22] Turkish Republic Highway Flexible Pavement Design Guide. 1995, Technical Research Unit Presidency, Ankara, pp. 93.

[23] Wu, Y. (1996). Aggregate Toughness-abrasion Resistance and Durability-soundness Tests Related to Asphalt Concrete Performance in Pavements. PhD Thesis. Auburn University, Auburn, Alabama.

[24] Yoder, E. J. (1975). Pavement Design, Construction, and Reconstruction, Section 16 in Handbook of Highway Engineering. Van Nostrand Reinhold Co., New York. 